\title{
The Effectiveness of a Crossword Puzzle Game in Improving Numeracy Ability of Kindergarten Children
}

\author{
Rakimahwati $^{1}$ \\ ${ }^{1}$ Universitas Negeri Padang, Indonesia \\ Correspondence: Rakimahwati, Early Childhood Care and Education Department, Faculty of Educational \\ Science, Universitas Negeri Padang, Padang, Indonesia. E-mail: rakimahwati10@yahoo.com
}

Received: January 16, 2014 Accepted: February 20, 2014 Online Published: February 28, 2014

doi:10.5539/ass.v10n5p79

URL: http://dx.doi.org/10.5539/ass.v10n5p79

\begin{abstract}
This research is motivated by the low numeracy ability of kindergarten children in Padang. The children still find it difficult to recognize the numbers, and the learning methods applied by teachers are less varied. This study aims at revealing the effectiveness of a crossword puzzle in improving numeracy ability of kindergarten children. This is a quantitative research with quasi experimental approach to compare between the children's ability in the experimental class and in the control class. The population of this study is the students of group B at TK Arrahim Padang. The sampling technique used is purposive sampling. Based on the calculation of the t-test, it is obtained that $t_{\text {calculated }}$ is 2.78 , while $t_{\text {table }}$ at the level of confidence $(\alpha)$ of 0.05 is 2.064 , so that $t_{\text {calculated }}>t_{\text {table, then the }}$ hypothesis can be accepted. It can be concluded that the use of a Crossword Puzzle Game is effective in improving numeracy ability of the kindergarten children.
\end{abstract}

Keywords: numeracy ability, crossword game, kindergarten

\section{Introduction}

Kindergarten is one of the Early Childhood Care and Education found in the formal education system. As an initial educational institution, the main task of kindergarten is to prepare children by introducing them to a variety of knowledge, attitudes or behavior, skills and intelligence in order to adapt themselves to the actual learning activities at elementary schools.

Education in kindergarten aims at facilitating the growth and the development of children as a whole in accordance with the norms of the values of life. Through education in kindergarten children are expected to develop all their potential both physically and psychologically which includes moral, social, economy, cognitive and language ability to be ready to enter further education.

According to Law No. 20 Year 2003 PART I Article 1, paragraph 14 about National Education System, it is stated that early childhood care and education is the developmental effort which is addressed to children from birth up to the age of six years which is done through the provision of educational stimulation to assist the growth and the physical and spiritual development so that children are ready to enter further education.

Developmental aspects that should be developed in kindergarten are developing habits that include: the development of moral and religious values, social development, emotional development, and self-reliance development. Basic skills development includes: language skills, cognitive skills, physical/motoric skills, and art skills. One of the cognitive skills that should be developed is the numeracy skill. In developing aspects of cognitive development there are a lot of things that can be learned by children, one of which is children can master various concepts of colours, sizes, shapes, directions, numbers, magnitudes, numerals, and others.

The result of preliminary observation that the researcher found in kindergarten TK Arrahim Padang is that the children's numeracy ability is still low. Children have not been fully able to recognize numbers. In order to stimulate the children's numeracy ability, the teacher rarely used games as a media in delivering the lesson. Often, the teacher only used counting textbooks, magazines, worksheets as media, and sometimes just used singing and question and answer methods, so that the children became less responsive in receiving the materials delivered by the teacher. Because the method used was less interesting and boring for the children, some of them often played by themselves or talked to their friends while the teacher was explaining the lesson. 
Looking at the above phenomena, the writer's main reason of doing this research is because using game in teaching is interesting; therefore, it can relieve the children's boredom in learning and can eventually enhance the children's numeracy ability.

According to the Ministry of Education (2000: 1), it is stated that arithmetic is a part of mathematics which is needed in developing numeracy skills which are very useful for everyday life, particularly the concept of numbers as the basis for the development of mathematical skills". Hence, numeracy skill in kindergarten is necessary to develop a basic knowledge of mathematics, so that the children are mentally ready to take a part in the further study of mathematics at elementary schools, such as the introduction of the concept of numbers, number symbols, colours, shapes, sizes, spaces, and positions through various forms of tools and fun playing activities.

Meanwhile, according to Sujiono (2008: 11.11) "Arithmetic is a way of learning about the name of numbers, then using those names of numbers to identify the number of the objects depending on the mind's ability to count them".In introducing arithmetic concept, the children are expected to be so active that it will have a longer impact on their memory about what they have learned. In the effort to improve the numeracy ability on the children's memory about what they have understood and memorized, the learning is presented through the procedures and steps which are appropriate, clear and attractive, i.e. by using media or game devices that can stimulate the children's interest and memory in terms of arithmetic.

Playing and children are an integral and inseparable unit. Activities performed by children always show the activities of playing. Therefore, one of the learning principles of early childhood care and education is through play. Moeslichatoen (2004) states that play is the demand and the essential need of kindergarten children. Through play, children can satisfy their demands and the needs of the development in dimension of their motoric, cognitive, creativity, language, emotion, social, values, and attitudes of life.

Meanwhile, Sujiono (2011) states that playing is an activity done by children all day, because through play children can explore, discover, express their feelings, picnic and learn with pleasure.In the implementation of arithmetic learning activities, a teacher plays a role in building the children's natural curiousity about arithmetic activities. The teacher's care about the children can be done by responding to whatever the results obtained by the children in learning arithmetic, so it will give confidence to the children. Therefore, teachers are required to be sensitive to the children's numeracy development.

Children can learn arithmetic through mathematic concept, which is through counting concrete objects, connecting numbers with number symbols and developing a concept of additon and subtraction. According to Suyanto (2005) the mathematic concepts of early childhood children include 1) Counting, that is connecting the object to the concept of numbers, starting from number one. If having been advanced, children can count multiple numbers, 2) Number, that is a symbol of quantity. Children can connect between the number of objects and the number symbols, 3) Classification, that is grouping the objects into several groups, for mathematics the group can be based on the object's size or its shape.

The Ministry of Education (2007) states "The concepts that have to be introduced include 1) one-to-one correspondence, 2) spelling, 3) the meaning of numbers and its introduction, 4) size, 5) addition and subtraction". Crossword puzzle is a game in which we have to fill the blank spaces in a box shape with the numbers corresponding to image clues. According to Cahyo (2011) a crossword puzzle game is a game of memorizing, searching and matching words / numbers. A crossword puzzle game relies on the ability of the left brain in memorizing, as well as the ability in matching the number that corresponds to the number of images in the box provided.

According to Nurjatmika (2012) a crossword puzzle game can be an optional playing activity for children if done in a pleasant situation. Learning arithmetic through the game will be more fun, and the children can use their imagination in choosing the correct number.

From those opinions, the writer thinks that a crossword puzzle game with images is also very good to improve the children's numeracy ability. This is because a crossword puzzle game is created by using image cards and number cards.

\section{Research Method}

This is a quantitative research with a quasi experimentaldesign. According to Arikunto (2009), a quasi experiment is a research that comes close to a true experiment where it is impossible to use a strict control or to manipulate all relevant variables, there must be a compromise in determining the internal and external validity that correspond to the existing limitations. 
This research aims at examining to what extent using a crossword puzzle game affects the children's mathematical development, especially the improvement in children's numeracy skills. The design in this research involves two groups, namely the experimental group and the control group, by comparing the learning results of the control and the experimental group. The experimental class is given treatment (X), while the control class is given a conventional treatment $(\mathrm{Y})$ and both classes are given equal assessment.

The population of this study is kindergarten students of Group B TK Arrahim Padang that consists of 49 children and is divided into 4 smaller groups: group B1, B2, B3 and B4. Considering that this study is a quasi experimental research, the two groups were selected by using purposive sampling technique, where the sample is taken from the group under particular consideration. Sugiyono (2011) describes purposive sampling as a sampling technique with particular considerations.

The type of data in this study is primary data i.e. the data which are directly obtained from the original data. The data are the scores of the test results conducted by the researcher. The source of the data is the group that has been selected as the sample of this research, that is group B1.

The research instrumentation used in the technique of collecting the data is a test. The technique of data analysis is the equality test of the two mean scores by using t-test before which the normality and homogeneity testwere conducted.

\section{Findings and Discussions}

\subsection{Data Description}

Data that were obtained from the post-test uses 13 pieces of research instruments, with the alternative assessment criteria of each instrument i.e. Very Good (VG), Good (G), Not Good (NG), and Extremely Not Good (ENG). Very Good is scored 4, Good is scored 3, Not Good is scored 2, and Extremely Not Good is scored 1. The data were also obtained from the results of the oral test given to the kindergarten students of group B1 at TK Arrahim Padang who were at the first semester of Academic Year 2013/2014. The number of students who were taught by using the Crossword Puzzle Game were 13 students. Having obtained the scores of the improvement of the students' numeracy ability, it could be seen that the highest score achieved by the students was 98 and the lowest one was 67 . While the data from the numeracy ability test results obtained by 13 students from class B2 (Control class) who were not treated by using Crossword Puzzle Game showed that the highest score that they could achieve was 92 and the lowest one was 51 . To see the comparison of the score between the numeracy ability of the students who were treated by using the Crossword Puzzle Game and the ones who were not treated by using the Crossword Puzzle Game is provided in Table 1:

Table 1. Descriptive analysis of sample

\begin{tabular}{lcccccc}
\hline Class & $\mathbf{n}$ & Min & Max & Mean & SD & SD $^{\mathbf{2}}$ \\
\hline Experimental & 13 & 67 & 98 & 83.3 & 9.74 & 94.86 \\
Control & 13 & 51 & 92 & 77.6 & 10.12 & 102.4 \\
\hline
\end{tabular}

From Table 1, the experimental class group of 13 students obtained the highest score of 98 and the lowest score was 67. From the scores of the students in the experimental group, the total score obtained was 1084, with a mean score of 83.3, Standard Deviation of 9.74 and the variance score of 94.86 .

While the control group consisting of 13 students using the conventional method got the highest score of 92 and the lowest score of 51. From the scores of the students of control group, the total score obtained was 1010 with a mean score of 77.6, standard deviation of 10.12 and the variance score of 102.4.

\subsection{Normality Testing}

The calculation of the normality test result can be seen in Table 2:

Table 2. Result of the normality test

\begin{tabular}{lcccc}
\multicolumn{1}{c}{ Class } & $\mathbf{N}$ & $\mathbf{A}$ & $\mathbf{L}_{\text {calculated }}$ & $\mathbf{L}_{\text {table }}$ \\
\hline Experimental & 13 & 0.05 & 0.1023 & 0.234 \\
Control & 13 & 0.05 & 0.1736 & 0.234 \\
\hline
\end{tabular}


Table 2 showed that:

a) Based on the statistical table, the result of the highest Lilliefors calculation for the experimental class is 0.1023 with $\mathrm{n}=13$, so the value of $\mathrm{L}$ in the table list is 0.234 with a significance level of 0.05 . So $\mathrm{L}_{\text {calculated }}<$ $\mathrm{L}_{\text {table }}=0.1023<0.234$, thus it can be concluded that the data come from normally distributed population.

Based on the statistical, the result of the highest Lilliefors calculation for the control class is 0.1736 with $n=13$, so the value of $\mathrm{L}$ in the table list is 0.234 with a significance level of 0.05 . So $\mathrm{L}_{\text {calculated }}<\mathrm{L}_{\text {table }}=0.1736<0.234$, thus it can be concluded that the data come from normally distributed population.3.3 Homogeneity Testing

The calculation of the homogeneity testing result is shown in Table 3:

Table 3. Result of homogeneity testing

\begin{tabular}{lcccc}
\hline \multicolumn{1}{c}{ Class } & A & Chi Square $\left(\mathbf{x}^{2}\right)$ calculated & Chi Square $\left(\mathbf{x}^{2}\right)$ table & Conclusion \\
\hline $\begin{array}{l}\text { Experimental } \\
\text { Control }\end{array}$ & 0.05 & 0.23026 & 3.841 & Homogeneous \\
\hline
\end{tabular}

Table 3 showed that with a df $(2-1)=1$, the value of chi square $\left(\chi^{2}\right)$ table is 3.841 which yields a significance level of 0.05 and the calculation of chi square $\left(\chi^{2}\right)$ is 0.23026 . Therefore, it can be concluded that the data come from homogeneous group.

\subsection{Hypothesis Testing}

Having known that both of the data are normally distributed and homogeneous, then inferential data analysis can be carried out by using t-test to see whether the hypothesis proposed in this research can be accepted or not. The result of hypothesis testing is shown in Table 4:

Table 4. Result of hypothesis testing

\begin{tabular}{lccc}
\hline \multicolumn{1}{c}{ Class } & $\mathbf{t}_{\text {calculated }}$ & $\mathbf{t}_{\text {table }}$ & Conclusion \\
\hline $\begin{array}{l}\text { Experimental } \\
\text { Control }\end{array}$ & 2,78 & 2,064 & $\mathrm{H}_{1}$ is accepted \\
\hline
\end{tabular}

Table 4 showed that $t_{\text {calculated }}>t_{\text {table }}$ at a significance level of 0.05 . Thus it can be interpreted that $H_{1}$ is accepted and $\mathrm{H}_{\mathrm{o}}$ is rejected. So it can be concluded that the use of the crossword puzzle game in improving the numeracy ability of early childhood children is more effective than conventional learning at kindergarten TK Arrahim Padang can be accepted. This means that there is a significant difference from the results of the numeracy ability development of the children in experimental class that use the crossword puzzle game if compared to those without using the crossword puzzle game.

\section{Discussions}

The research findings show that after the treatment is given to the students both in the experimental and control class, the score obtained by the students in the experimental class is more prominent than the control class. In the experimental class, the highest score obtained by the students is 98 , while in the control class the highest score is 92.

From the data analysis that has been done, it can be seen that there is a significant difference between the experimental class that uses the crossword puzzle game in improving the students' numeracy ability and the control class that uses only conventional learning in introducing arithmetic. According to Suyanto (2005), early childhood children's arithmetic is learning to think logically and mathematically in a fun and uncomplicated way. This is proved by the high achievement level of the children towards the numbers which are introduced through games. Besides, this fact is also indicated by the children's total score which is much different between the experimental class and the control class.

Then, the result of the data analysis that has been done shows that $t_{\text {calculated }}>t_{\text {table }}$, this indicates that the use of the crossword puzzle game is effective in improving the numeracy development of the children at kindergarten TK 
Arrahim Padang. This means that the opinion which is stated in the hypothesis in this research can be accepted. This means that the improvement in the development of early childhood children's numeracy ability by using the crossword puzzle game is considered effective when compared with the class that does not use the crossword puzzle game. Based on the finding of this research, in the class that is treated by using the crossword puzzle game in improving the children's numeracy development, the children's numeracy ability improves very high. In the learning process, the children look active, where in the crossword puzzle game the children are stimulated to be able to mention the numbers and search for the numbers. After that the children can arrange those numbers on the board of the crossword puzzle game in accordance with the existing image clues.

In child development, arithmetic plays a very important role for Early Childhood Children, because the age of one to six years is known as the most important period in the childhood development. In order to improve their numeracy development, the children need to get a stimulus that can attract their interest to be eager to learn arithmetic.

Based on what have been mentioned above, arithmetic should be introduced since early ages at school. This is due to the fact that introducing arithmetic since early ages would be easier than learning arithmetic in adulthood. Children tend to prefer to learn arithmetic when it is introduced through games so it will be easier for them to memorize.

One of the important factors in introducing arithemtic to children is the media that can attract the children's interests, so the communication between teachers and children will take place effectively. Children often feel bored because the learning methods used are less attractive, and therefore, the children become lazy to learn.

Using a crossword puzzle game as a media that aims at helping children to improve their numeracy developmentis more attractive and proven to improve the children's ability in learning arithmetic.Then, it can be seen that in the experimental class that the mean score obtained by the children is higher than that in the control class. In the experimental class, improvement in the numeracy development of the children is based on the condition which is both effective and immediate, because in this approach, the teacher gives more guidance. From the description of the discussion above, the writer concludes that the crossword puzzle game is effectively used in improving the early childhood children's numeracy development at kindergarten TK Arrahim Padang.

\section{Conclusions and Suggestions}

Based on the research data analysis that has been done, it can be concluded that:

1) The findings of this research show that the experimental group that uses the Crossword Puzzle Game in improving the children's numeracy development gets "higher" mean score than the control group that does not use the Crossword Puzzle Game. It is clear that the use of the Crossword Puzzle Game is effective in improving the early childhood children's numeracy ability.

2) There is a significant difference between the experimental group that uses the Crossword Puzzle Game compared with the group that does not use the Crossword Puzzle Game in improving the Early Childhood Children's numeracy ability.

Based on the findings of the research mentioned above, some suggestions are proposed as follows:

1) It is suggested for teachers who will introduce arithmetic to Early Childhood Children to use a Crossword Puzzle Game in improving the children's numeracy ability. A Crossword Puzzle Game will attract the children's interest so that they can be more motivated and more excited to participate in learning activities.

2) It is suggested for researchers who want to pursue this research can to apply this game at other schools.

\section{References}

Arikunto. (2009). Manajemen Penelitian. Jakarta: Rineka Cipta.

Cahyo, A. (2011). Gudang Permainan Kreatif Khusus Asah Otak Kiri Anak. Jogjakarta: FlashBooks.

Depdiknas. (2000). Pedoman Permainan Berhitung Permulaan di Taman Kanak Kanak. Jakarta: Depdiknas.

Moeslichatoen. (2004). Metode Pengajaran di Taman Kanak-kanak. Jakarta: PT Rineka Cipta.

Nurjatmika, Y. (2012). Ragam Aktivitas Harian Untuk TK. Jogjakarta: Diva Press.

Sugiyono. (2011). Metode Penelitian Pendidikan. Bandung: Alfabeta.

Sujiono, B. (2008). Metode Pengembangan Kognitif. Jakarta: Universitas Terbuka.

Sujiono, Y. N. (2011). Konsep Dasar Pendidikan Anak Usia Dini. Jakarta: PT Indeks. 
Suyanto, S. (2005). Konsep Dasar Pendidiskan Anak Usia Dini. Jakarta: Depdiknas.

\section{Copyrights}

Copyright for this article is retained by the author(s), with first publication rights granted to the journal.

This is an open-access article distributed under the terms and conditions of the Creative Commons Attribution license (http://creativecommons.org/licenses/by/3.0/). 